Article

\title{
The Association of IL-1 and HRAS Gene Polymorphisms with Breast Cancer Susceptibility in a Jordanian Population of Arab Descent: A Genotype-Phenotype Study
}

\author{
Laith N. AL-Eitan ${ }^{1,2, *}$, , Bashar H. Al-Ahmad ${ }^{1}$ and Fouad A. Almomani ${ }^{1}$ \\ 1 Department of Applied Biological Sciences, Jordan University of Science and Technology, Irbid 22110, Jordan; \\ bmalkawi0@gmail.com (B.H.A.-A.); fouad57@just.edu.jo (F.A.A.) \\ 2 Department of Biotechnology and Genetic Engineering, Jordan University of Science and Technology, \\ Irbid 22110, Jordan \\ * Correspondence: Ineitan@just.edu.jo; Tel.: +962-2-7201000 (ext. 23464); Fax: +962-2-7201071
}

Received: 14 December 2019; Accepted: 15 January 2020; Published: 23 January 2020

\begin{abstract}
Breast cancer (BC) pathogenesis is poorly understood and not yet completely determined. BC susceptibility genes are responsible for $20 \%$ to $25 \%$ of breast cancer risk. The main objective of this study is to identify the genetic polymorphisms within the Harvey rat sarcoma viral oncogene homolog (HRAS1) and interleukin-1 receptor antagonist (IL1-Ra) genes in Jordanian BC female patients and to investigate the genetic association of these polymorphisms with BC. Samples were collected from 150 Jordanian BC patients and 187 healthy age-matched controls. PCR and PCR-RFLP techniques were used to identify genetic polymorphisms within these candidate genes. The single nucleotide polymorphism single nucleotide polymorphism (SNP) association web tool SNPStats (v. 3.6) was used to investigate the allelic and genotypic association with BC. Different statistical analyses were used to study the correlation between the investigated genetic variants and several prognosis factors of BC. A genetic association between BC susceptibility and Il- $1 \beta$ rs1143634 was found specifically at the allelic level of E1 as a risk allele (72\% in the cases vs. $64.2 \%$ in the controls). Another genetic association was found in the IL-Ra gene (86-VNTR (variable number tandem repeat)), which presented one repeat allele $(24.1 \%$ in cases vs. $15.59 \%$ in controls) and could be considered as a risk allele in Jordanian women. In contrast, this study found that there is no genetic association between Il-1 $\beta$ SNP rs16944 and BC. In addition, a significant association was found between the allelic level of the HRAS1 gene and BC susceptibility. Since this study is the first to be conducted on the genetic susceptibility of these genes to BC in the Jordanian population, more investigations on the link between $\mathrm{BC}$ and these variants are recommended to determine the impact of these polymorphisms on other ethnic groups.
\end{abstract}

Keywords: breast cancer; genetic association; single nucleotide polymorphism; HRAS; IL-1; cancer susceptibility

\section{Introduction}

Breast cancer $(B C)$ is an accumulation of different malignancies that present in the mammary glands. $\mathrm{BC}$ has the highest incidence of all cancers in women worldwide [1]. Among the Jordanian population, $\mathrm{BC}$ was ranked number one of the three most common cancers among Jordanian females, as reported by the Jordan Cancer Registry [2]. It was also reported to be the second cause of death after cardiovascular diseases among women [3]. According to the Ministry of Health, BC accounted 
for nearly $40 \%$ of all cancers that affect Jordanian women, with the median age at first diagnosis being 51 [3].

BC etiology is complex as many genes are involved in multiple stages of cancer development [4]. Genetic mutations can lead to $B C$ and have been experimentally linked to some tumor markers, including progesterone receptor (PR), estrogen receptor (ER), and human epidermal growth factor receptor type 2 (HER2) statuses, which are used clinically in the classification of BC [5]. The cellular heterogeneity of $\mathrm{BC}$ and many genes involved in regulating cell differentiation, growth, and death highlights the significance of investigating the effects of multiple genetic alterations in BC development and progression [6]. Many candidate gene studies have been performed to identify the genes that contribute to $\mathrm{BC}$ development in the Jordanian population. In one study, using mutation analysis, it was found that most screened mutations were present in the BRCA1 exon 11 gene [7]. Another study found that Jordanians of Circassian descent have a higher risk of $B C$ than their Arab counterparts [8]. Moreover, the 5'UTR polymorphism of the XRCC gene was found to be significantly different between Jordanian BC patients and the healthy population [9]. A significant association between MTHFR polymorphisms and the incidence of BC in Jordanian women was also found, especially in the 41-60 age demographic [10]. Recently, several genetic association studies of $B C$ have been conducted in Jordanian women [11-19] to investigate the genetic association of several candidate genes with BC susceptibility. None of the Jordanian studies have investigated the effect of genetic polymorphisms of the interleukin 1 (IL-1) and Harvey rat sarcoma viral oncogene homolog (HRAS) genes on the genetic susceptibility of BC. The IL-1 gene is located on chromosome 2 (q14.1) and encodes the interleukin 1 protein [20-22]. This type of protein is considered a cytokine, which, at low concentrations, can affect several types of cells and organs. The IL-1 cytokine has a wide range of roles in adaptive and innate immune responses. Several genetic polymorphisms, such as rs16944 (C/T) and rs1143627 (T/C), within the IL-1 gene have been reported to play a major role in the genetic susceptibility of deferent cancers [23]. Moreover, the HRAS gene is located on chromosome 11 (p15.5) and is considered to be a small monomeric protein with GTPase activity [1,24]. The HRAS gene has been the subject of conflicting reports with regard to its role in $B C$ development and progression. It has been reported that increased expression of HRAS is associated with more aggressive breast cancer tumors [25], while in another study, it was observed that HRAS mutations were rarely found in breast cancer tumors [26].

To the best of our knowledge IL-1 and HRAS gene polymorphisms have never been examined to detect their associations with an increased risk of $\mathrm{BC}$ among the Jordanian population. Herein, we describe the roles of the variable number tandem repeat (VNTR) polymorphism of the HRAS gene and the single nucleotide polymorphism (SNPs) of the IL-1 gene in Jordanian BC patients.

\section{Results}

\subsection{Patient Characteristics}

Whole pathological reports were obtained for all selected patients. Table 1 shows the major demographic, clinical, and histopathological characteristics of the cohort. A total of $30.8 \%$ of the recruited patients had a family history of $\mathrm{BC}$. The minimum age of menopause was 35 , and the maximum age was 59 , with an average age $( \pm \mathrm{SD})$ of $47.9 \pm 5.3$. Also, most of the cases were invasive carcinoma $(82.2 \%)$, and in $50 \%$ of all cases, the lymph nodes were free of tumors. Furthermore, histologic reports for each patient showed that $73 \%$ of tumors express the Estrogen Hormone Receptor, $42.8 \%$ express the prostergon Hormone Receptor, and only $43.8 \%$ express the HER2 receptor. 
Table 1. Clinical and pathological characteristics for selected breast cancer patients.

\begin{tabular}{|c|c|c|c|c|c|}
\hline \multicolumn{2}{|c|}{ Clinical Characteristics } & \multirow{2}{*}{$\begin{array}{c}\begin{array}{c}\text { Frequency } \\
\text { N (\%) }\end{array} \\
36(24.6 \%)\end{array}$} & \multicolumn{2}{|c|}{ Pathological Characteristics } & \multirow{2}{*}{$\begin{array}{c}\begin{array}{c}\text { Frequency } \\
\text { N (\%) }\end{array} \\
57(42.8 \%)\end{array}$} \\
\hline Body mass & $\leq 25$ & & he & Positive & \\
\hline index (BMI) & $>25$ & $110(75.4 \%)$ & receptor & Negative & $76(57.2 \%)$ \\
\hline \multirow{2}{*}{$\begin{array}{l}\text { First pregnancy } \\
\text { (age) }\end{array}$} & $<20$ & $38(30.4 \%)$ & \multirow{2}{*}{ Estrogen receptor } & Positive & $95(73 \%)$ \\
\hline & $\geq 20$ & $87(69.6 \%)$ & & Negative & $35(27 \%)$ \\
\hline \multirow{2}{*}{$\begin{array}{l}\text { Age at breast } \\
\text { cancer } \\
\text { diagnosis }\end{array}$} & $<45$ & $50(34.2 \%)$ & \multirow{2}{*}{ Tumor differentiation } & $\begin{array}{l}\text { Low. } \\
\text { differentiation }\end{array}$ & $43(32.5 \%)$ \\
\hline & $\geq 45$ & $96(75.8 \%)$ & & $\begin{array}{l}\text { Mid and High. } \\
\text { differentiation }\end{array}$ & $89(67.5 \%)$ \\
\hline \multirow{2}{*}{$\begin{array}{l}\text { Age at first } \\
\text { menstruation }\end{array}$} & $<13$ & $45(31.1 \%)$ & \multirow{2}{*}{$\begin{array}{l}\text { Axillary lymph } \\
\text { nodes }\end{array}$} & Free of tumor & $72(50 \%)$ \\
\hline & $\geq 13$ & $100(68.9 \%)$ & & $\begin{array}{l}\text { Show metastatic } \\
\text { Carcinoma }\end{array}$ & $72(50 \%)$ \\
\hline \multirow{2}{*}{$\begin{array}{l}\text { Breastfeeding } \\
\text { status }\end{array}$} & Yes & $91(62.8 \%)$ & \multirow{2}{*}{ Tumor stage } & PT1-PT2 & $127(93.3 \%)$ \\
\hline & No & $54(37.2 \%)$ & & PT3-PT4 & $9(6.7 \%)$ \\
\hline \multirow{2}{*}{$\begin{array}{l}\text { Age at } \\
\text { menopause }\end{array}$} & $<50$ & $37(56.1 \%)$ & \multirow{2}{*}{$\begin{array}{l}\text { Histology } \\
\text { classification }\end{array}$} & in situ carcinoma & $24(17.7 \%)$ \\
\hline & $\geq 50$ & $29(43.9 \%)$ & & invasive carcinoma & $111(82.2 \%)$ \\
\hline \multirow{2}{*}{ Family history } & Yes & $45(31 \%)$ & \multirow{3}{*}{ Tumor size } & $\leq 2 \mathrm{~cm}$ & $36(26.9 \%)$ \\
\hline & No & $101(69 \%)$ & & $2<x \leq 5$ & $53(39.5 \%)$ \\
\hline \multirow{2}{*}{ Allergy } & Yes & $37(25.3 \%)$ & & $>5$ & $45(33.6 \%)$ \\
\hline & No & $109(74.7 \%)$ & \multirow{2}{*}{$\begin{array}{l}\text { Lymph node } \\
\text { involvement }\end{array}$} & Yes & $121(84 \%)$ \\
\hline \multirow{2}{*}{ Smoking } & Yes & $38(26.9 \%)$ & & No & $23(16 \%)$ \\
\hline & No & $103(73.1 \%)$ & \multirow{3}{*}{$\begin{array}{l}\text { Human epidermal } \\
\text { growth factor } \\
\text { receptor } 2 \text { (Her2) } \\
\text { marker }\end{array}$} & Positive & $43(43.9 \%)$ \\
\hline \multirow{2}{*}{ Co-morbidity } & Yes & $68(47.2 \%)$ & & Negative & $55(56.1 \%)$ \\
\hline & No & $75(52.8 \%)$ & & & \\
\hline
\end{tabular}

\subsection{Hardy-Weinberg Equilibrium (HWE) Test}

The Hardy-Weinberg Equilibrium test (HWE) was performed to examine the normal distribution of polymorphisms within IL-1 $\beta$ (promoter region and exon5) in both the cases and in the control groups. All the studied SNPs met the HWE standards in both the BC patients and healthy individuals and were included in the current study. The minor alleles of the studied SNPs and their frequencies for both the cases and controls are shown in Table S2.

\subsection{IL-1 Gene Polymorphisms and their Associations with BC Risk}

The frequency distribution of the genotyped polymorphisms (rs16944 within the Il-1 $\beta$ promoter region, rs1143634 within the Il-1 $\beta$ exon 5 region, and $86 \mathrm{bp}$-VNTR within IL-1Ra) within the IL-1 gene and their associations with $\mathrm{BC}$ were evaluated among both $\mathrm{BC}$ patients and healthy individuals (Table 2). These genetic associations were conducted using case-control genetic analysis (http: //www.quantpsy.org/chisq/chisq.htm) in order to determine if there is a significant difference between the different genotypes and alleles and BC susceptibility, as shown in Table 2.

\subsubsection{Genetic Association of rs16944 Polymorphisms with the Risk of BC}

The genotypes of the Il-1 $\beta$ rs16944 SNP were analyzed using PCR-RFLP and subsequent gel electrophoresis. Figure 1A shows the different genotypes using gel electrophoresis. Three genotypes were detected based on their band sizes. Homozygous (C/C) genotype and homozygous (T/T) genotypes were present at sizes of $190+114 \mathrm{bp}$ and $304 \mathrm{bp}$, respectively, while the presence of heterozygous alleles (C/T) was indicated by the appearance of both bands (190 bp + $114 \mathrm{bp}$ and $304 \mathrm{bp}$ ). 
The genotype frequencies of these polymorphisms are presented in Table 2. The results of this study show no significant differences between the cases and the healthy control with a chi-square $=1.364$ and a $p$-value $=0.521$, with an odds ratio and $95 \% \mathrm{CI}, \mathrm{C} / \mathrm{C}=1, \mathrm{C} / \mathrm{T}=1.02(0.64-1.64)$, and TT $=1.42$ (0.67-2.63). Moreover, in allelic frequency, the BC patients did not significantly differ from the healthy individuals with a chi-square $=0.986$ and a $p$-value $=0.342$, with an odds ratio and $95 \%$ CI, C $=1.064$ (0.941-1.204), $\mathrm{T}=0.909$ (0.754-1.097). The homozygous TT allele was more frequent in the cases $(19.9 \%)$ than in the controls $(15 \%)$, while the CC allele and heterozygous CT allele were less frequent in the cases $(37.1 \%$ and $43 \%$ ) than in the healthy controls (39.8\% and $45.2 \%)$, respectively. At the allelic level, the $\mathrm{C}$ allele was less frequent in the cases $(58.6 \%)$ than in the healthy control $(62.4 \%)$, while the $\mathrm{T}$ allele was more frequent in the cases $(41.4 \%)$ than in the control $(37.6 \%)$, which indicates that the $\mathrm{T}$ allele and the TT genotype were more prevalent in the BC in the current study.

\subsubsection{Genetic Association of rs 1143634 with the Risk of BC}

The second SNP in the same cluster within the Il-1 $\beta$ gene is rs1143634, which was analyzed using PCR-RFLP. Figure 1B presents the results of different genotypes using gel electrophoresis. In total, three genotypes were detected: a homozygous (E1/E1) genotype at a size of $135+114 \mathrm{bp}$ and a homozygous (E2/E2) genotype at $249 \mathrm{bp}$, while the heterozygous allele (E1/E2) presented both bands (135 $+114 \mathrm{bp}$, $249 \mathrm{bp})$.

This study found that the rs1143634 differs between BC patients and healthy individuals, as shown in Table 2. This polymorphism has an odds ratio and 95\% CI (E1/E1 $=1, \mathrm{E} 1 / \mathrm{E} 2=0.59(0.37-0.93)$, and $\mathrm{E} 2 / \mathrm{E} 2=0.59(0.27-1.26))$. Additionally, the allele frequencies between the BC patients and healthy individuals were significant with a chi-square $=4.577$ and a $p$-value $=0.038$, with an odds ratio and $95 \%$ CI $(\mathrm{E} 1=0.892(0.804-0.989), \mathrm{E} 2=1.278(1.018-1.604))$. For example, the heterozygous allele E1/E2 was more frequent in the healthy individuals $(49.2 \%)$ than in the studied BC patients $(38.5 \%)$, while the homozygous alleles E1/E1 and E2/E2 were more frequent in the BC patients $(52.7 \%$ and $8.8 \%)$ than in the healthy individuals (39.6\% and $11.2 \%$ ), respectively. At the allelic level, the E1 allele was more frequent in BC patients $(72 \%)$ than in healthy individuals $(64.2 \%)$, while the E2 allele was less frequent in BC patients (28\%) than in healthy individuals (35.8\%). These results indicate that the risk allele for $\mathrm{BC}$ patients in this study could be the E1 allele.

\subsubsection{Genetic Association of IL-1Ra 86bp-VNTR with the Risk of BC}

The genotypes of the $86 \mathrm{bp}$-VNTR were analyzed using PCR followed by gel electrophoresis. Figure $1 \mathrm{C}$ shows the different genotypes using agarose gel electrophoresis. Nine different genotypes were detected according to the number of repeats, composed of the following alleles: Allele (1) was present at a size of $240 \mathrm{bp}$, allele (2) at $325 \mathrm{bp}$, allele (3) at $410 \mathrm{bp}$, and allele (4) at $500 \mathrm{bp}$. All the homozygous genotypes had the same allele size $(1 / 1,3 / 3,4 / 4)$, while the heterozygous genotype had two different alleles $(1 / 2,1 / 3,1 / 4,2 / 3,2 / 4,3 / 4)$.

The genotype frequencies of $86 \mathrm{bp}$-VNTR showed the highest association with BC susceptibility. Further, the genotype frequency in the $\mathrm{BC}$ patient group differed significantly from that of the healthy individuals, with a $p$-value $=0.014$. In addition, the allele frequencies between the BC patients and healthy individuals were significantly different, with a $p$-value $=0.0003$, as shown in Table 2. Most of the repeats were not different between the BC patients (65.1\%) and healthy individuals (48.3\%), except for the $3 / 3$ repeat. However, the $1 / 1$ repeat at the genotypic level and the 1 repeat at the allelic level are significantly associated with a risk of BC.

\subsection{Genetic Association of the HRAS1 28bp-VNTR Polymorphism with the Risk of BC}

A total of four common alleles (a1, a2, a3, and a4) were identified to correspond to PCR product sizes of $924 \mathrm{bp}, 1300 \mathrm{bp}, 1900 \mathrm{bp}$, and $2350 \mathrm{bp}$, respectively, while the rare HRAS1 VNTR alleles were shown to be the increment or decrement of one or more repeat motifs $(28 \mathrm{bp})$ from the four common alleles. Figure 1D shows some common and rare genotypes of the 28bp-VNTR polymorphism. 
Table 2 shows the common/common, common/rare, and rare/rare genotypes. These genotype frequencies were not significantly different between the $\mathrm{BC}$ patients and healthy individuals $(p$-value $=0.812, \mathrm{OR}(95 \% \mathrm{CI}), \mathrm{C} / \mathrm{C}=1$ (not applicable), $\mathrm{C} / \mathrm{R}=1.11(0.58-2.14)$ and $\mathrm{R} / \mathrm{R}=0.82$ (0.40-1.68)). This study also shows that the CC and CR genotypes were slightly more frequent in BC patients (67.7\% and $13.7 \%)$ than in healthy individuals $(67.1 \%$ and $12.2 \%)$. In contrast, the RR genotype was less frequent in the cases $(9.6 \%)$ than in the control $(11.7 \%)$. The rare and common allele frequencies of the BC patients and healthy individuals are shown in Table 3 . These results show a significant association with BC at the allelic level, with an estimated overall $p$-value $=0.022$. The current study shows that the most frequent allele within common alleles is A1 in both BC patients $(81.5 \%)$ and healthy individuals $(78.6 \%)$, while the most frequent rare allele is $\mathrm{A} 1+2$ within $\mathrm{BC}$ patients $(4.5 \%)$ and healthy individuals $(4.2 \%)$.
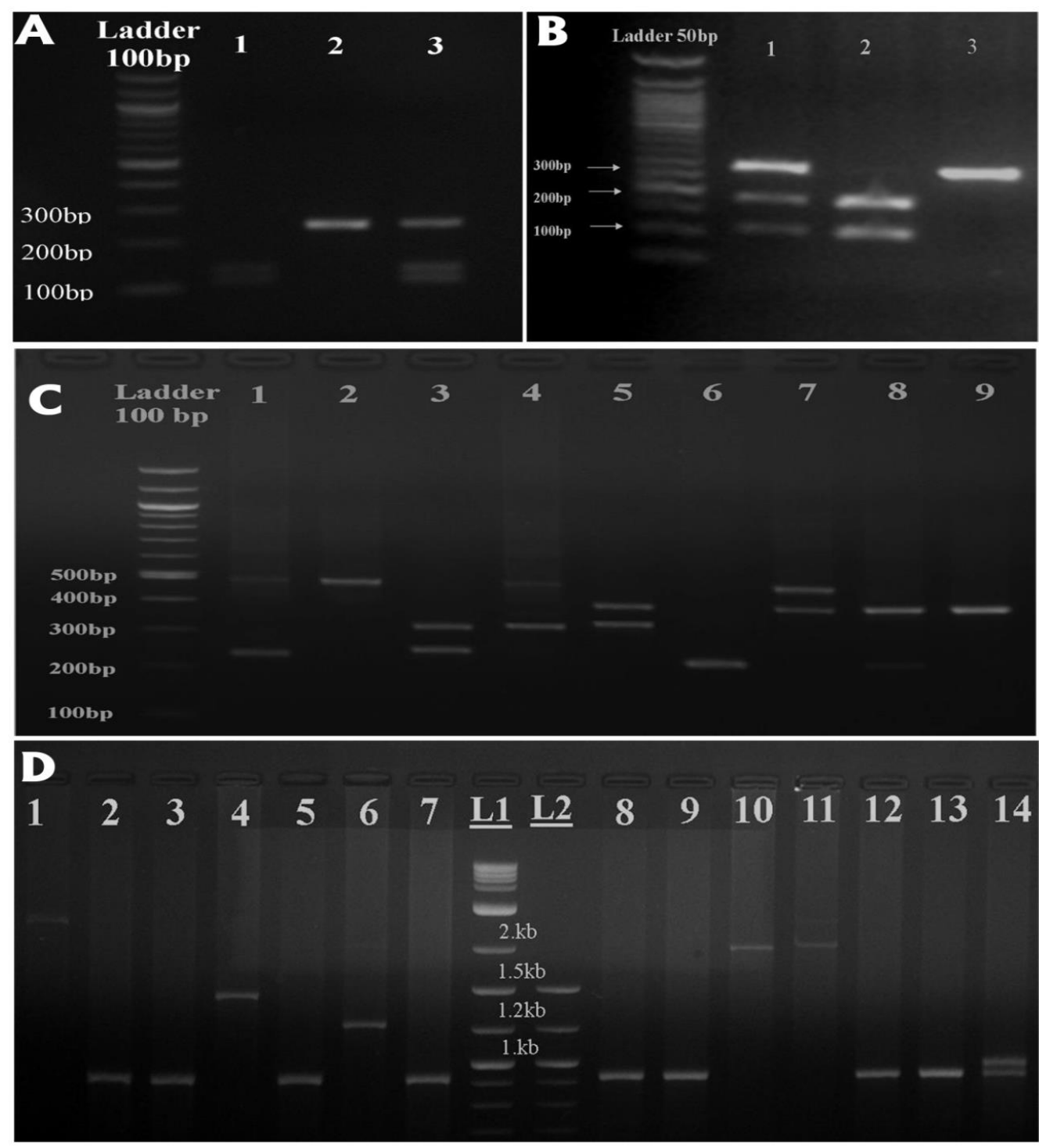

Figure 1. Agarose gel electrophoresis showing different polymorphisms in the $I L-1$ and $H R A S$ genes: (A) PCR-RFLP genotypes in the IL-1 promoter gene according to the single nucleotide polymorphism (SNP) rs16944. (B) PCR-RFLP genotypes in the IL-1 exon5 gene according to the SNP rs1143634. (C) Variable number tandem repeat (VNTR) genotypes in the $I L-1 R a$ variable number polymorphism with 86 bp repeats. (D) VNTR genotypes in the HRAS1 gene variable number polymorphism with 28 bp repeats. 
Table 2. Distribution and association of the investigated IL-1 gene cluster (Il-1 $\beta$ promoter, exon 5 , and IL-1Ra) and HRAS1 gene polymorphisms and breast cancer (BC).

\begin{tabular}{|c|c|c|c|c|c|}
\hline \multirow[b]{2}{*}{ Polymorphism } & \multicolumn{5}{|c|}{ Allelic and Genotypic Frequencies in the Cases and Controls } \\
\hline & Allele/Genotype & Cases $(n=150)$ & $\begin{array}{l}\text { Controls } \\
(n=188)\end{array}$ & $p$-value * & Chi-Square \\
\hline \multirow{5}{*}{$\begin{array}{l}\text { Il-1 } \beta \text { promoter } \\
\text { rs16944 }\end{array}$} & $\mathrm{C}$ & $177(58.6 \%)$ & $232(62.4 \%)$ & \multirow{2}{*}{0.342} & \multirow[b]{2}{*}{0.986} \\
\hline & $\mathrm{T}$ & $125(41.4 \%)$ & $140(37.6 \%)$ & & \\
\hline & $\mathrm{CC}$ & $56(37.1 \%)$ & $74(39.8 \%)$ & \multirow{3}{*}{0.521} & \multirow{3}{*}{1.364} \\
\hline & CT & $65(43.0 \%)$ & $84(45.2 \%)$ & & \\
\hline & TT & $30(19.9 \%)$ & $28(15 \%)$ & & \\
\hline \multirow{4}{*}{$\begin{array}{l}\text { Il-1 } 1 \beta \text { exon5 } \\
\text { rs1143634 }\end{array}$} & E1 & $213(72.0 \%)$ & $240(64.2 \%)$ & \multirow{2}{*}{0.038} & \multirow{2}{*}{4.577} \\
\hline & E2 & $83(28.0 \%)$ & $134(35.8 \%)$ & & \\
\hline & E1E1 & $78(52.7 \%)$ & $74(39.6 \%)$ & \multirow{2}{*}{0.057} & \multirow{2}{*}{5.747} \\
\hline & E1E2 & $57(38.5 \%)$ & $92(49.2 \%)$ & & \\
\hline \multirow{13}{*}{$\begin{array}{c}\text { IL-1RA } \\
\text { 86bp-VNTR }\end{array}$} & 1 & 70 (24.1\%) & $58(15.59 \%)$ & \multirow{4}{*}{0.0003} & \multirow{4}{*}{18.258} \\
\hline & 2 & $8(2.7 \%)$ & $1(0.2 \%)$ & & \\
\hline & 3 & $196(67.5 \%)$ & $299(80.3 \%)$ & & \\
\hline & 4 & $16(5.51 \%)$ & $14(3.76 \%)$ & & \\
\hline & $1 / 1$ & $9(6.2 \%)$ & $5(2.7 \%)$ & \multirow{9}{*}{0.014} & \multirow{9}{*}{18.364} \\
\hline & $3 / 3$ & $70(48.3 \%)$ & $121(65.1 \%)$ & & \\
\hline & $4 / 4$ & $2(1.4 \%)$ & $1(0.5 \%)$ & & \\
\hline & $1 / 2$ & $2(1.4 \%)$ & $0(0 \%)$ & & \\
\hline & $1 / 3$ & $46(31.7 \%)$ & $46(24.7 \%)$ & & \\
\hline & $1 / 4$ & $4(2.8 \%)$ & $2(1.1)$ & & \\
\hline & $2 / 3$ & $4(2.8 \%)$ & $1(0.5 \%)$ & & \\
\hline & $2 / 4$ & $2(1.4 \%)$ & $0(0 \%)$ & & \\
\hline & $3 / 4$ & $6(4.1 \%)$ & $9(4.8 \%)$ & & \\
\hline \multirow{3}{*}{$\begin{array}{l}\text { HRAS1 gene } \\
\text { 28bp-VNTR }\end{array}$} & $\mathrm{CC}^{*}$ & $112(76.7 \%)$ & $137(76.1 \%)$ & \multirow{3}{*}{0.812} & \multirow{3}{*}{0.464} \\
\hline & $C R *$ & 20 (13.7\%) & $22(12.2 \%)$ & & \\
\hline & $R R$ * & $14(9.6 \%)$ & $21(11.7 \%)$ & & \\
\hline
\end{tabular}

$p$-value $<0.05$ is considered to be significant, $C^{*}$ : common/common alleles, CR: common/rare alleles, RR: rare/rare alleles.

Table 3. Distribution and association of the investigated HRAS1 VNTR and breast cancer (BC).

\begin{tabular}{cccc}
\hline HRAS1 Alleles & Cases & Controls & $p$-value \\
\hline Common Alleles & & & \\
\hline A1 & $238(81.5 \%)$ & $283(78.6 \%)$ & 0.368 \\
A2 & $6(2.1 \%)$ & $11(3.1 \%)$ & 0.423 \\
A3 & $2(0.7 \%)$ & 0 & 0.109 \\
A4 & $1(0.3 \%)$ & $2(0.6 \%)$ & 0.689 \\
\hline Rare Alleles & \multicolumn{3}{c}{} \\
\hline A1+2 & $13(4.5 \%)$ & $15(4.2 \%)$ & 0.841 \\
A1+3 & $2(0.7 \%)$ & $3(0.8 \%)$ & 0.841 \\
A1+4 & $5(1.7 \%)$ & 0 & 0.011 \\
A1+5 & 0 & $1(0.3 \%)$ & 0.368 \\
A1+6 & $2(0.7 \%)$ & 0 & 0.109 \\
A1-1 & $4(1.4 \%)$ & $5(1.4 \%)$ & 1 \\
A1-2 & $2(0.7 \%)$ & $8(2.2 \%)$ & 0.109 \\
A1-5 & 0 & $1(0.3 \%)$ & 0.368 \\
A2+2 & 0 & $5(1.4 \%)$ & 0.045 \\
A2+3 & $9(3.1 \%)$ & $9(2.5 \%)$ & 0.61 \\
A2+4 & $1(0.3 \%)$ & 0 & 0.31 \\
A2+6 & $1(0.3 \%)$ & $1(0.3 \%)$ & 0.920 \\
A3+3 & $2(0.7 \%)$ & 0 & 0.109 \\
A3+4 & $2(0.7 \%)$ & $4(1.1 \%)$ & 0.548 \\
A3+6 & 0 & $1(0.3 \%)$ & 0.368 \\
A4+3 & $1(0.3 \%)$ & $8(2.2 \%)$ & 0.045 \\
A4+4 & $1(0.3 \%)$ & 0 & 0.31 \\
A4+5 & 0 & $2(0.6 \%)$ & 0.193 \\
A4+6 & 0 & $1(0.3 \%)$ & 0.368 \\
\hline
\end{tabular}




\subsection{Association between the IL-1 Cluster and HRAS1 Gene Polymorphisms and the Clinico-Pathological} Characteristics of Breast Cancer (BC)

We investigated the association between the polymorphisms of the IL-1 and HRAS1 genes and clinical and pathological characteristics of BC. The results are shown in Table 4 with the estimated $p$-value for each clinical characteristic. We detected five significant $p$-values that correlated these polymorphisms with age at menopause, co-morbidity, tumor differentiation, tumor stage, and breastfeeding status $(0.02$ at IL-1Ra, $<0.0001$ at HRAS1, $<0.0001$ at rs1143634, 0.016 at IL-1Ra, and 0.044 at HRAS1, respectively).

Table 4. The association between different IL-1 clusters and HRAS1 gene polymorphism genotypes and the clinico-pathological characteristics of breast cancer (BC).

\begin{tabular}{|c|c|c|c|c|}
\hline \multirow{2}{*}{$\begin{array}{l}\text { Clinical } \\
\text { Characteristics }\end{array}$} & \multicolumn{3}{|c|}{ Il-1gene Cluster } & \multirow{2}{*}{$\begin{array}{l}\text { HRAS1gene } \\
\text { 28bp-VNTR }\end{array}$} \\
\hline & rs:16944 & rs1143634 & IL-1R 86 bp-VNTR & \\
\hline \multirow{2}{*}{ Body mass index } & $0.802^{a}$ & $0.885^{\mathrm{a}}$ & $0.944^{\mathrm{a}}$ & $0.341^{\mathrm{a}}$ \\
\hline & $0.221^{c}$ & $0.122^{c}$ & $0350^{c}$ & $1.084^{\mathrm{c}}$ \\
\hline \multirow{2}{*}{ Age at first pregnancy } & $0.414^{\mathrm{a}}$ & $0.188^{a}$ & $0.945^{\mathrm{a}}$ & $0.498^{\mathrm{a}}$ \\
\hline & $0.889^{c}$ & $1.694^{c}$ & $0.375^{c}$ & $0.701^{\mathrm{c}}$ \\
\hline \multirow{2}{*}{ Age at $B C$ diagnosis } & $0.344^{\mathrm{a}}$ & $0.266^{\mathrm{a}}$ & $0.646^{\mathrm{a}}$ & $0.308^{a}$ \\
\hline & $1.08^{c}$ & $1.337^{c}$ & $0.769^{c}$ & $1.186^{c}$ \\
\hline \multirow{2}{*}{ Allergy } & $0.980^{\mathrm{a}}$ & $0.866^{\mathrm{a}}$ & $0.178^{\mathrm{a}}$ & $0.481^{\mathrm{a}}$ \\
\hline & $0.040^{b}$ & $0.122^{c}$ & $11.44^{\mathrm{b}}$ & $1.464^{b}$ \\
\hline \multirow{2}{*}{ Age at menarche } & $0.957^{\mathrm{a}}$ & $0.347^{\mathrm{a}}$ & $0.765^{\mathrm{a}}$ & $0.577^{\mathrm{a}}$ \\
\hline & $0.044^{c}$ & $1.068^{c}$ & $0.614^{c}$ & $0.553^{c}$ \\
\hline \multirow{2}{*}{ Breastfeeding status } & $0.206^{c}$ & $0.285^{a}$ & $0.786^{\mathrm{a}}$ & $0.044^{\mathrm{a}}$ \\
\hline & $3.159^{b}$ & $2.508^{b}$ & $4.726^{b}$ & $6.264^{b}$ \\
\hline \multirow{2}{*}{ Age at menopause } & $0.364^{\mathrm{a}}$ & $0.908^{a}$ & $0.02^{\mathrm{a}}$ & $0.659^{a}$ \\
\hline & $1.027^{\mathrm{c}}$ & $0.097^{c}$ & $2.791^{c}$ & $0.420^{c}$ \\
\hline \multirow{2}{*}{ Family history } & $0.835^{\mathrm{a}}$ & $0.416^{\mathrm{a}}$ & $0.489^{\mathrm{a}}$ & $0.323^{a}$ \\
\hline & $0.361^{\mathrm{b}}$ & $1.752^{b}$ & $7.448^{b}$ & $2.257^{b}$ \\
\hline \multirow{2}{*}{ Co-morbidity } & $0.452^{\mathrm{a}}$ & $0.834^{\mathrm{a}}$ & $0.438^{\mathrm{a}}$ & $<0.0001^{\mathrm{a}}$ \\
\hline & $1.588^{b}$ & $0.363^{b}$ & $7.957^{b}$ & $151.2^{\mathrm{b}}$ \\
\hline \multirow{2}{*}{ Smoking } & $0.369^{a}$ & $0.960^{\mathrm{a}}$ & $0.327^{\mathrm{a}}$ & $0.153^{\mathrm{a}}$ \\
\hline & $0.127^{b}$ & $0.81^{\mathrm{b}}$ & $9.182^{b}$ & $3.757^{b}$ \\
\hline \multirow{2}{*}{ Progesterone receptor status } & $0.425^{\mathrm{a}}$ & $0.864^{\mathrm{a}}$ & $0.605^{\mathrm{a}}$ & $0.491^{\mathrm{a}}$ \\
\hline & $1.713^{b}$ & $0.293^{b}$ & $6.377^{b}$ & $1.424^{b}$ \\
\hline \multirow{2}{*}{ Estrogen receptor status } & $0.940^{\mathrm{a}}$ & $0.179^{\mathrm{a}}$ & $0.184^{\mathrm{a}}$ & $0.433^{\mathrm{a}}$ \\
\hline & $0.124^{\mathrm{b}}$ & $3.345^{b}$ & $11.32^{b}$ & $18.35^{b}$ \\
\hline \multirow{2}{*}{ HER2 } & $0.207^{\mathrm{a}}$ & $0.649^{a}$ & $0.750^{\mathrm{a}}$ & $0.633^{a}$ \\
\hline & $3.150^{b}$ & $0.865^{b}$ & $5.071^{b}$ & $0.914^{\mathrm{b}}$ \\
\hline \multirow[b]{2}{*}{ Tumor differentiation } & $0.697^{\mathrm{a}}$ & $<0.0001^{\mathrm{a}}$ & $0.160^{\mathrm{a}}$ & $0.304^{\mathrm{a}}$ \\
\hline & $0.722^{b}$ & $138.5^{\mathrm{b}}$ & $10.53^{b}$ & $10.59^{b}$ \\
\hline \multirow{2}{*}{ Axillary lymph nodes } & $0.505^{\mathrm{a}}$ & $0.677^{\mathrm{a}}$ & $0.316^{\mathrm{a}}$ & $0.930^{\mathrm{a}}$ \\
\hline & $1.367^{\mathrm{b}}$ & $0.779^{b}$ & $9.322^{b}$ & $0.146^{\mathrm{b}}$ \\
\hline \multirow{2}{*}{ Tumor stage } & $0.797^{\mathrm{a}}$ & $0.459^{a}$ & $0.016^{\mathrm{a}}$ & $0.606^{\mathrm{a}}$ \\
\hline & $0.454^{b}$ & $1.559^{b}$ & $18.80^{b}$ & $1.627^{b}$ \\
\hline \multirow{2}{*}{ Histology classification } & $0.949^{a}$ & $0.721^{\mathrm{a}}$ & $0.281^{\mathrm{a}}$ & $0.347^{\mathrm{a}}$ \\
\hline & $0.104^{b}$ & $0.655^{b}$ & $9.781^{b}$ & $2.119^{b}$ \\
\hline \multirow[b]{2}{*}{ Tumor size } & $0.529^{a}$ & $0.924^{\mathrm{a}}$ & $0.901^{\mathrm{a}}$ & $0.519^{a}$ \\
\hline & $0.640^{c}$ & $0.079^{c}$ & $0.429^{c}$ & $0.659^{c}$ \\
\hline \multirow{2}{*}{ Lymph node involvement } & $0.794^{\mathrm{a}}$ & $0.807^{\mathrm{a}}$ & $0.180^{a}$ & $0.989^{a}$ \\
\hline & $0.460^{b}$ & $1.612^{b}$ & $11.39^{b}$ & $0.311^{b}$ \\
\hline
\end{tabular}

a A $p$-Value $<0.05$ is considered to be significant; ${ }^{\mathrm{b}}$ A Pearson's chi-squared test was used to determine the genotype-phenotype association; ${ }^{c}$ An Analysis of variance (ANOVA) test was used to determine the genotype-phenotype association. 


\section{Discussion}

The candidate IL-1 (rs16944, rs1143634, 86bp-VNTR) and HRAS1 (28bp-VNTR) gene polymorphisms have been reported to play a major role in $\mathrm{BC}$ risk. These polymorphisms were chosen according to their significant functional relevance and their location inside the gene [27,28].

This study was designed to examine the genetic association between the candidate gene polymorphisms and BC susceptibility in the Jordanian population. This study is considered the first study of its kind to describe and detect the association between IL-1 and HRAS1 SNP and VNTR polymorphisms and BC in a Jordanian population of Arab descent. Our results illustrate that there is a highly significant association between both the IL-1Ra gene within the second intron region and the $I L-1$ exon $5+3953$ and the risk of BC among Jordanian Arabs.

The genes encoding the $I L-1$ family are mapped on chromosome $2 q 14$ and are composed of two cytokines, $I L-1$ alpha $(I L-\alpha)$ and IL-1 beta $(I L-\beta)$, in addition to the $I L-1 R a$ receptor antagonist. Our target in this gene was the following cluster: $I l-1 \beta$ promoter, exon5, and $I L-1 R a$. In the Caucasian population, no significant association was found between both the IL-1RN and IL-1beta genes and the risk of $\mathrm{BC}$ within them, except for the $511 \mathrm{C} / \mathrm{T}$ polymorphisms in the interleukin 1 beta (IL1B) promoter region polymorphism, which was related to the tumor stage and lymph node involvement phenotypes [29]. Moreover, a significant association of the IL-1RN (variable number 240/410 alleles) polymorphism with the risk of malignant BC was reported in Indian women [22]. In the present study, we described a group of clinical and pathological features that might be associated with increased $\mathrm{BC}$ risk among Jordanian women. Five significant $p$-values were detected for the age at menopause, co-morbidity, tumor differentiation, tumor stage, and breastfeeding status, which had $p$-values of 0.02 at IL-1Ra, <0.0001 at HRAS1, <0.0001 at $r s 1143634,0.016$ at IL-1Ra, and 0.044 at HRAS1.

A genetic association was found between BC susceptibility and the rs1143634 SNP, which is located in exon 5 of the Il-1 $\beta$ gene, specifically at the allelic level of E1 as a risk allele (72\% in cases vs. $64.2 \%$ in controls). Another significant association was found within this cluster for the 86bp-VNTR of the IL Ra gene with repeat number 1 (24.1\% in the cases vs. $15.59 \%$ in the controls) as a risk allele, which has the highest association with $\mathrm{BC}$ risk among the studied polymorphisms. These results confirm the strong role of these polymorphisms in the risk of $\mathrm{BC}$ - especially the $1 / 1$ repeat genotype and 1 repeat allele. The frequency and distribution of the genetic polymorphisms of the IL-1 gene cluster (Il- $1 \beta$ promoter, exon5, and IL-1Ra) within other populations in comparison to the Jordanian population are presented in Tables S3-S5. In terms of the genotypic frequencies of the Il-1 $\beta$ gene polymorphisms (as illustrated in Table S3 and in accordance with the other population data), there is no association between the Il-1 $\beta$ promoter polymorphism and the risk of BC. These findings are very similar to those of the previous works that have been conducted on Caucasian populations in Germany and in the UK.

Moreover, the current study found that the results of this research in regards to the Il-1 $\beta$ exon 5 polymorphism are similar to those of the Germany Caucasian study (Table S4), with a $p$-value 0.057 at the genotypic level. In addition, the results in our study were significantly associated with the risk of BC ( $p$-value $=0.0003)$ when we compared the $(\mathrm{E} 1)$ and (E2) allele frequencies of the IL-1Ra gene polymorphism between $\mathrm{BC}$ patients and healthy individuals.

The present study reported that the IL-1Ra gene polymorphism has the strongest statistical association with BC, which is similar to the results obtained by the Korean study but was not similar to the Caucasian and Indian studies (Table S5).

Finally, no genetic association was found between the HRAS rare genotypes and BC risk in the current Jordanian study. However at the allelic level, there is a significant association between the a3 and a4 alleles and the risk of BC [24]. Correspondingly, it was determined that rare alleles in the HRAS VNTR were significantly associated with the risk of BC [1].

In agreement with previous data and studies, our results showed that there was no association between HRAS1 and BC at the genotypic level, but, in contrast, HRAS1 was significantly associated with BC susceptibility at the allelic level. There was a significant association with BC susceptibility at the allelic level, especially for the A1 allele, with an overall $p$-value $=0.022$. Moreover, allele A1 
is considered to be a risk allele associated with BC. The frequency of the HRAS1 28-VNTR variant compared to other populations is illustrated in Table S6. Following the Caucasian population (among whom there is an association at the allelic level between the risk of $\mathrm{BC}$ and genetic polymorphisms within the HRAS1 gene), our study also showed a significant association of HRAS1 gene variants with the risk of $\mathrm{BC}$ only at the allelic level.

\section{Materials and Methods}

\subsection{Studied Population}

A total of 150 females recruited from the Breast Surgery Clinic in the Royal Medical Services (RMS) were randomly selected for a retrospective study. In addition, 187 unrelated healthy Jordanian females with no breast cancer history were used as the control. The control group was recruited from the blood bank at the RMS. The average age $( \pm$ SD) of the cohort was $53.1 \pm 13.1$ years, with a median of 51 and a range of (22 to 95 ). The average age $( \pm S D)$ was $36.6 \pm 10.9$ years with a median of 37 (ranging from (18 to 73) years) for the control group. This study was established according to the provisions of the Human Ethics Standard of Jordan University of Science and Technology and in compliance with the Intuitional Review Board (IRB) Guidelines at the Jordan University of Science and Technology. Approval for the patient's recruitment, including blood samples and clinical data collection, were also obtained from the Human Ethics Committee at the (RMS). In addition, written informed consent was obtained from all subjects in the study. Each participant was informed about why this study was being conducted, why clinical data were obtained from the medical records, and what the aims, benefits, and details of this study were.

\subsection{DNA Extraction and Quantification of Isolated Genomic DNA}

Blood samples were previously collected into EDTA tubes $(5 \mathrm{~mL})$ at the (RMS) laboratories, from both the patients and their matched healthy controls. Extraction of genomic DNA was performed using a Gentra ${ }^{\circledR}$ Puregene ${ }^{\circledR}$ Blood Kit (Qiagen, Germany) following the manufacturer's protocol. The DNA concentration $(\mathrm{ng} / \mu \mathrm{L})$ and purity (A260/280) was measured by a Nano-Drop ND-1000 UV-Vis Spectrophotometer (BioDrop, UK), and the blank was $1.5 \mu \mathrm{L}$ of DNA rehydration solution. The DNA concentration was calculated using the $\mathrm{c}=\left(\mathrm{A}^{*} \mathrm{e}\right) / \mathrm{b}$ equation, where $\mathrm{c}$ is the nucleic acid concentration $(\mathrm{ng} / \mu \mathrm{L}), \mathrm{A}$ is the absorbance, $\mathrm{e}$ is the wavelength-dependent extinction coefficient in $\mathrm{ng}-\mathrm{cm} / \mu \mathrm{L}$, and $\mathrm{b}$ is the path length in $\mathrm{cm}$.

\subsection{DNA Genotyping}

The polymerase chain reaction (PCR) and restriction fragment length polymorphism (RFLP) techniques were used to identify genetic polymorphisms within these candidate genes. PCR was performed using a Veriti Thermal Cycler (Applied Biosystems, Foster City, CA, USA.)). The program details are shown in Table S1. The separation of PCR products of the IL-1Ra intron 2 gene was performed using a $2 \%$ agarose gel. Similarly, PCR products of the region with the VNTR polymorphism in the HRAS1 gene were separated with a $1 \%$ agarose gel. Bands were observed using ultraviolet illumination, and images of the gels were captured by an AlphaImager ${ }^{\circledR}$ Mini system (Protein Simple, San Jose, CA, USA) [26,27].

\subsection{DNA Genotyping Using PCR-RFLP}

\subsubsection{IL-1 $\beta$ rs16944 SNP Genotyping}

The allele of the SNP was determined using the RFLP technique. Briefly, the PCR reaction, PCR program, primers, and annealing temperatures are shown in Table S1. A total of $10 \mu \mathrm{L}$ of PCR product was added to $10 \mu \mathrm{L}$ restriction enzyme ( $0.2 \mu \mathrm{L}$ Ava1 enzyme), $1 \mu \mathrm{L}$ cut smart buffer, and $8.8 \mu \mathrm{L}$ nuclease-free water. The mixture was spun down and then incubated for $5 \mathrm{~h}$ at $65^{\circ} \mathrm{C}$. Next, $10 \mu \mathrm{L}$ 
of each digested PCR product was separated by electrophoresis with a $2 \%$ agarose gel. Bands were visualized using ultraviolet illumination, and images of the gels were taken by an AlphaImager ${ }^{\circledR}$ Mini system (Protein Simple, San Jose, CA, USA) [26].

\subsubsection{IL-1ß (rs1143634) and SNP genotyping}

The genotypes of rs1143634 SNP were determined by the PCR technique, as described previously in [26]. The PCR program, primers, and annealing temperatures are summarized in Table S1 [26].

\subsection{Statistical Analysis}

The SNP association web tool snpStats (v. 3.6) was used to count allele frequencies. In addition, SNPStats was also used to calculate the genotype frequency for each allele using the Hardy-Weinberg equilibrium equation ( $\mathrm{p} 2+2 \mathrm{pq}+\mathrm{q} 2=1)$. In order to define the $p$-values for allele and genotypic association, a Chi-square test (Pearson $\chi 2$ test) and ANOVA test were used (http://www.quantpsy.org/ chisq/chisq.htm) to determine if there are significant differences between the expected, observed, and calculated genotype frequencies between BC patients and healthy individuals. A $p$-value $<0.050$ was considered to be statically significant.

\subsection{Ethics Committee Approval and Patient Consent}

Ethical approval was obtained from the Intuitional Review Board (IRB), with ethical code number 32/104/2017 at the Jordan University of Science and Technology. Written informed consent was obtained from all participants. In this study, the collected samples were obtained from the Jordanian Royal Medical Services (JRMS).

\section{Conclusions}

To the best of our Knowledge, this study is the first of its kind to investigate the genetic association of IL-1 (rs16944, rs1143634, IL-Ira 86bp VNTR) and HRAS1 (28bp-VNTR) gene polymorphisms with the risk of $\mathrm{BC}$ in a Jordanian population of Arab descent. We found that there is a genetic association between BC susceptibility and he IL-1Ra gene VNTR (24.1\% in cases vs. $15.59 \%$ in controls), with repeat number 1 as a risk allele. Moreover, this study revealed that there is a significant association at the allelic level of rs1143634 SNP within the Il-1 $\beta$ gene, with E1 as a risk allele ( $72 \%$ in cases vs. $64.2 \%$ in controls). In contrast, there is no genetic association between rs16944 SNP within the Il-1 $\beta$ gene and the risk of $\mathrm{BC}$. In addition, a significant genetic association with the risk of $\mathrm{BC}$ was also found for the 28bp-VNTR within the HRAS1 gene, specifically with the A1 allele.

Finally, it is obvious that BC pathogenesis in Jordanian Arab women is predisposed to different genetic factors compared to that in other ethnicities. While all of the genetic polymorphisms included in this study have been previously suggested to play a major role in BC among other ethnicities, only rs16944 and IL-1Ra 86bp VNTR showed a significant association with BC or its risk and prognosis in Jordanians. As few genetic association and pharmacogenomic studies have been conducted in Jordan [30,31], a multi-center and multi-ethnic approach should be applied in future studies to build a genetic landscape profile for BC among Jordanian women.

Supplementary Materials: The following are available online at http://www.mdpi.com/2072-6694/12/2/283/s1, Table S1: Primers, annealing temperatures, PCR product sizes and restriction enzymes that were used for genotyping of $I L-1$ (rs16944, rs1143634, IL-Ira 86bp VNTR) and HRAS1 (28bp-VNTR) gene. Table S2: Il-1 $\beta$ gene polymorphisms and their minor allele frequencies, and HWE p-values in cases and control. Table S3: Frequency of IL1B promoter gene polymorphisms in different populations. Table S4: Frequency of IL1B exon 5 gene polymorphisms in different populations. Table S5: Genetic association studies of IL-1Ra gene polymorphisms in different populations. Table S6: Frequency of HRAS1 gene polymorphisms in different populations.

Author Contributions: Conceptualization, L.N.A.-E.; data curation, L.N.A.-E.; formal analysis, L.N.A.-E. and B.H.A.-A.; funding acquisition, L.N.A.-E.; investigation, L.N.A.-E., B.H.A.-A. and F.A.A.; methodology, L.N.A.-E., B.H.A.-A. and F.A.A.; project administration, L.N.A.-E.; resources, L.N.A.-E. and F.A.A.; software, L.N.A.-E.; supervision, L.N.A.-E.; validation, L.N.A.-E.; visualization, L.N.A.-E.; writing一original draft, L.N.A.-E, B.H.A.-A., 
and F.A.A.; writing-review and editing, L.N.A.-E., B.H.A.-A. and F.A.A. All authors have read and agreed to the published version of the manuscript.

Funding: Jordan University of Science and Technology: 355/2018.

Acknowledgments: First, the authors thank the Royal Medical Services for approving the present study. This study was funded by the Deanship of Research (RN: 355/2018), Jordan University of Science and Technology.

Conflicts of Interest: The authors declare no conflict of interest.

\section{References}

1. Zhang, C.; Yu, G.L.X. Current evidence on the relationship between HRAS1 polymorphism and breast cancer risk: A meta-analysis. Breast Cancer Res. Treat. 2011, 128, 467-472. [CrossRef] [PubMed]

2. Alsaraireh, A.; Darawad, M.W. Impact of a Breast Cancer Educational Program on Female University Students' Knowledge, Attitudes, and Practices. J. Cancer Educ. 2017, 34, 1-8. [CrossRef] [PubMed]

3. Abdel-Razeq, H.; Attiga, F.; Mansour, A. Cancer care in Jordan. Hematol. Oncol. Stem Cell Ther. 2015, 8, 64-70. [CrossRef] [PubMed]

4. Tao, Z.; Shi, A.; Lu, C. Breast Cancer: Epidemiology and Etiology. Cell Biochem. Biophys. 2015, 72, $333-338$. [CrossRef] [PubMed]

5. Perou, C.M.; Sùrlie, T.; Eisen, M.B.; Van De Rijn, M.; Jeffrey, S.S.; Rees, C.A.; Pollack, J.R.; Ross, D.T.; Johnsen, H.; Akslen, L.A.; et al. Molecular portraits of human breast tumours. Nature 2000, 406, 747-752. [CrossRef] [PubMed]

6. Sørlie, T.; Perou, C.M.; Tibshirani, R.; Aas, T.; Geisler, S.; Johnsen, H.; Hastie, T.; Eisen, M.B.; Van De Rijn, M.; Jeffrey, S.S.; et al. Gene expression patterns of breast carcinomas distinguish tumor subclasses with clinical implications. Proc. Natl. Acad. Sci. USA 2001, 98, 10869-10874. [CrossRef]

7. Atoum, M.F.; Al-Kayed, S.A. Mutation analysis of the breast cancer gene BRCA1 among breast cancer Jordanian females. Saudi Med. J. 2004, 25, 60-63.

8. Mahasneh, A.A.; Abdel-hafiz, S.S. Polymorphism of p53 gene in Jordanian population and possible associations with breast cancer and lung adenocarcinoma. Saudi Med. J. 2004, 25, 1568-1573.

9. Al Zoubi, M.A. X-ray repair cross-complementing protein 1 and 3 polymorphisms and susceptibility of breast cancer in a Jordanian population. Saudi Med. J. 2015, 36, 1163-1167. [CrossRef]

10. Awwad, N.; Yousef, A.; Abuhaliema, A.; Abdalla, I. Relationship between Genetic Polymorphisms in MTHFR (C677T, A1298C and their Haplotypes) and the Incidence of Breast Cancer among Jordanian Females-Case-Control Study. Asian Pac. J. Cancer Prev. 2015, 16, 5007-5011. [CrossRef]

11. AL-Eitan, L.N.; Jamous, R.I.; Khasawneh, R.H. Candidate Gene Analysis of Breast Cancer in the Jordanian Population of Arab Descent: A Case-Control Study. Cancer Investig. 2017, 35, 256-270. [CrossRef] [PubMed]

12. AL-Eitan, L.; Rababa'h, D.; Alghamdi, M.; Khasawneh, R. Correlation between Candidate Single Nucleotide Variants and Several Clinicopathological Risk Factors Related to Breast Cancer in Jordanian Women: A Genotype-Phenotype Study. J. Cancer 2019, 10, 4647-4654. [CrossRef] [PubMed]

13. AL-Eitan, L.; Rababa'h, D.; Alghamdi, M.; Khasawneh, R. Association of GSTM1, GSTT1 and GSTP1 Polymorphisms with Breast Cancer among Jordanian Women. Onco Targets Ther. 2019, 12, 7757-7765. [CrossRef] [PubMed]

14. AL-Eitan, L.; Rababa'h, D.; Alghamdi, M.; Khasawneh, R. Role of Four ABC Transporter Genes in Pharmacogenetic Susceptibility to Breast Cancer in Jordanian Patients. J. Oncol. 2019, 1-8. [CrossRef]

15. AL-Eitan, L.; Rababa'h, D.; Alghamdi, M.; Khasawneh, R. Association of CYP gene polymorphisms with breast cancer risk and prognostic factors in the Jordanian population. BMC Med. Genet. 2019, 20, 148. [CrossRef]

16. AL-Eitan, L.; Rababa'h, D.; Alghamdi, M.; Khasawneh, R. The influence of an IL-4 variable number tandem repeat (VNTR) polymorphism on breast cancer susceptibility. Pharmgenom. Pers. Med. 2019, 12, 201-207. [CrossRef]

17. AL-Eitan, L.; Rababa'h, D.; Alghamdi, M.; Khasawneh, R. Genetic association of XRCC5 gene polymorphisms with breast cancer among Jordanian women. Onco Targets Ther. 2019, 12, 7923-7928. [CrossRef]

18. AL-Eitan, L.; Rababa'h, D. Correlation between a variable number tandem repeat (VNTR) polymorphism in SMYD3 gene and breast cancer: A genotype-phenotype study. Gene 2019, 728, 144281. [CrossRef] 
19. AL-Eitan, L.; Rababa'h, D.M.; Alghamdi, M.; Khasawneh, R. Association between ESR1, ESR2, HER2, UGT1A4, and UGT2B7 polymorphisms and breast Cancer in Jordan: A case-control study. BMC Cancer 2019, 19, 1257. [CrossRef]

20. Lee, K.; Park, S.K.; Hamajima, N.; Tajima, K.; Choi, J.; Noh, D.; Ahn, S.; Yoo, K.; Hirvonen, A. Genetic polymorphisms of interleukin-1 beta (IL-1B) and IL-1 receptor antagonist (IL-1RN) and breast cancer risk in Korean women. Breast Cancer Res. Treat. 2006, 96, 197-202. [CrossRef]

21. Liu, J.; Zhai, X.; Jin, G.; Hu, Z.; Wang, S.; Wang, X.; Qin, J.; Gao, J. Functional variants in the promoter of interleukin- $1 \mathrm{~b}$ are associated with an increased risk of breast cancer: A case-control analysis in a Chinese population. Int. J. Cancer 2006, 118, 2554-2558. [CrossRef] [PubMed]

22. Konwar, R.; Chaudhary, P.; Kumar, S.; Mishra, D.; Chattopadhyay, N.; Bid, H.K. Breast Cancer Risk Associated with Polymorphisms of IL-1RN and IL-4 Gene in Indian Women. Oncol. Res. Featur. Preclin. Clin. Cancer Ther. 2009, 17, 367-372. [CrossRef] [PubMed]

23. Zienolddiny, S.; Ryberg, D.; Maggini, V.; Skaug, V.; Canzian, F.; Haugen, A. Polymorphisms of the interleukin-1 $\beta$ gene are associated with increased risk of non-small cell lung cancer. Int. J. Cancer 2004, 109, 353-356. [CrossRef] [PubMed]

24. Tamimi, R.M.; Hankinson, S.E.; Ding, S.; Gagalang, V.; Larson, G.P.; Spiegelman, D.; Colditz, G.A.; Krontiris, T.G.; Hunter, D.J. The HRAS1 Variable Number of Tandem Repeats and Risk of Breast Cancer. Cancer Epidemiol. Biomark. Prev. 2003, 12, 1528-1530.

25. Yong, H.; Cells, E.; Yong, H.Y.; Hwang, J.; Son, H. Identification of H-Ras-Specific Motif for the Activation of Invasive Signaling Program in human breast epithelial cells. Neoplasia 2011, 13, 98-107. [CrossRef]

26. Myers, M.B.; Banda, M.; Mckim, K.L.; Wang, Y.; Powell, M.J.; Parsons, B.L. Breast Cancer Heterogeneity Examined by High-Sensitivity Quantification of PIK3CA, KRAS, HRAS, and BRAF Mutations in Normal Breast and Ductal. Neoplasia 2016, 18, 253-263. [CrossRef]

27. Manchanda, P.K.; Bid, H.K.; Mittal, R.D. Ethnicity greatly influences the interleukin-1 gene cluster (IL-1b promoter, exon-5 and IL-1Ra) polymorphisms: A pilot study of a north Indian population. Asian Pac. J. Cancer Prev. 2005, 6, 541-546.

28. Van Gils, C.H.; Conway, K.; Li, Y.; Taylor, J.A. HRAS1 variable number of tandem repeats polymorphism and risk of bladder cancer. Int. J. Cancer 2004, 100, 414-418. [CrossRef]

29. Hefler, L.A.; Grimm, C.; Lantzsch, T.; Lampe, D.; Leodolter, S.; Koelbl, H.; Heinze, G.; Reinthaller, A.; Tong-Cacsire, D.; Tempter, C.; et al. Interleukin-1 and interleukin- 6 gene polymorphisms and the risk of breast cancer in Caucasian women. Clin. Cancer Res. 2005, 11, 5718-5721. [CrossRef]

30. AL-Eitan, L.; Haddad, Y. Emergence of pharmacogenomics in academic medicine and public health in Jordan: History, present state and prospects. Curr. Pharmacogenom. Pers. Med. 2014, 12,167-175. [CrossRef]

31. AL-Eitan, L.; Tarkhan, A. Practical challenges and translational issues in pharmacogenomics and personalized medicine from 2010 onwards. Curr. Pharmacogenom. Pers. Med. 2014, 14, 7-17. [CrossRef] 